\title{
The Effect of Learning Motivation, Self-Efficacy, and Blended Learning on Students' Achievement in The Industrial Revolution 4.0
}

\author{
https://doi.org/10.3991/ijet.v15i08.12525 \\ Ryan Hidayat Rafiola ( ${ }^{\bowtie}$, Punaji Setyosari, Carolina Ligya Radjah, \\ M. Ramli, \\ State University of Malang, Malang, Indonesia \\ ryan.hidayat.1701119@students.um.ac.id
}

\begin{abstract}
This study aims to analyze the effect of learning motivation, selfefficacy, and blended learning on students' achievement in the industrial revolution 4.0. This is done to follow the development of the world of education to improve the quality of service, Human Resources and the quality of graduates. The research object was Public High School in Padang, Sampling using Slovin formula. To analyze the research data used Partial Least Square (PLS) Version 3.0. The results showed that (1) Learning Motivation had a positive and significant effect on students' achievement of Public High School in Padang, (2) SelfEfficacy had no significant effect on students' achievement of Public High School in Padang, (3) Blended learning had a positive and significant effect on achievement learning of Public High School in Padang, and (4) Learning Motivation, Self-Efficacy, and Blended Learning together have a significant effect on the Students' Achievement of Public High School in Padang.
\end{abstract}

Keywords-Learning motivation, self-efficacy, blended learning, students' achievement, industrial revolution 4.0

\section{Introduction}

Right now, we are facing the fourth industrial revolution known as the Industrial Revolution 4.0. To deal with these changes in innovation, education is also an important thing that is required to experience significant changes to face Industrial Revolution 4.0. Emerging technologies have a profound effect on public education. Only qualified and highly educated people can control this technology [1]. The development and progress of a nation are determined by the level of educational success. Learning activities that are in accordance by the development and changes in educational paradigms are learning activities that can synergize the cognitive, affective, and psychomotor domains simultaneously [2].

The development of computer science and technology as a learning medium has been widely used in every aspect. Teaching with computer media can inspire and motivate students to learn, optimize the classroom environment [3]. Life skills or 
innovative skills for living in the era of the industrial revolution 4.0 consist of leadership, collaboration, creativity, digital literacy, effective communication, emotional intelligence, entrepreneurship, global citizens, problem solving and teamwork.

The role of technology supports the teaching and learning process in this digital age because it can help students to become independent learners. This means that students can learn everything and anywhere by clicking on many features or platforms on the internet related to the subjects they are learning. In the teaching and learning process, teachers use many platforms to support their teaching and learning process, the way teachers give assignments, where they focus on developing student skills, and how teachers assess students. Teachers also try to focus on student-centered learning. Thus, students are more active and develop their critical thinking towards learning.

Blended learning is one solution to address the various needs of educational institutions throughout the world. Blended Learning is a combination of traditional classrooms and online learning. This combination provides better learning outcomes [4]. Combining internet technology and face-to-face interaction can improve pedagogy and easier access to information [5]. Blended teaching can facilitate an independent and collaborative learning experience. Blended learning builds a community of inquiry and a free and interactive dialogue platform. The way students speak supports mixed learning [6]. Digital literate students increase the possibility of expanding their learning and conversations outside the classroom [7]. According to [8] the use of cellular technology in education offers new opportunities to integrate face-to-face learning and online learning. The implementation of mobile learning and blended learning is not optimal due to the lack of design of the teaching system, for that mixed learning scenarios are used by combining various forms of learning and integrating various ways to access content using cellular technology.

To support the achievement of educational goals, the Public High School in Padang continues to keep abreast of developments in the world of education to improve the quality of services, Human Resources and the quality of its graduates. In an educational process, a student is said to be successful if he/she can complete the education program on time with good learning outcomes. That achievement or learning outcomes are the realization of potential skills or capacity that a person has. At school, learning outcomes or learning achievements can be seen from students' mastery of the subjects they have taken [9].

The problem that occurs of Public High School in Padang is the decline in student achievement. This can be identified by decreasing the average value of the report cards of Public High School in Padang as follows. 
Table 1. The average Report Cards of Public High School in Padang

\begin{tabular}{|l|c|l|}
\hline \multicolumn{1}{|c|}{ Academic Year } & Semester & \multicolumn{1}{c|}{ Average Value } \\
\hline \multirow{2}{*}{$2015 / 2016$} & 1 & 86.5 \\
\cline { 2 - 3 } & 2 & 86.2 \\
\hline \multirow{2}{*}{$2016 / 2017$} & 1 & 85.6 \\
\hline \multirow{2}{*}{$2017 / 2018$} & 2 & 85.5 \\
\hline \multirow{2}{*}{$2018 / 2019$} & 1 & 85.2 \\
\cline { 2 - 3 } & 2 & 84.2 \\
\cline { 2 - 3 } & 1 & 82.5 \\
\hline
\end{tabular}

To find out these factors, the researchers conducted a Pre-research as an initial description of this study. The initial pre-research was conducted by researchers by interviewing 35 students of Public High School in Padang to find out what are the main factors increased learning achievement. The instrument used in the pre-research is divided into 2 (two) parts, where students are asked to rank 3 (three) factors that can improve learning achievement based on the choices provided. In the second part, students are asked to answer several questions with alternative answers to "yes" and "no" to the factors chosen in the first part. The following are some of the variables that influence learning achievement based on pre-research results.

Table 2. Factors that influence students' achievement in Public High School in Padang

\begin{tabular}{|l|l|l|}
\hline \multicolumn{1}{|c|}{ Problem Indicator } & \multicolumn{1}{|c|}{ Number of People } & \multicolumn{1}{c|}{ Percentage (\%) } \\
\hline Learning motivation & 13 & 37 \\
\hline Self-efficacy & 10 & 28 \\
\hline Blended learning & 9 & 26 \\
\hline Parental support & 2 & 6 \\
\hline Teacher performance & 1 & 3 \\
\hline Total & 35 & 100 \\
\hline
\end{tabular}

Based on preliminary results, it is known that the factors that predominantly affect learning achievement are learning motivation, self-efficacy, and blended learning. These results become a reference for researchers to test the factors that influence learning achievement significantly.

\section{Relevant Literature}

\subsection{Learning motivation}

The motivation is a symptom in the form of effort or strength in a person that causes the impulse to carry out activities to achieve a certain goal [10]. Motivation is everything that drives someone to do something [11]. Learning motivation contains basic components, namely needs, goals, and encouragement [12]. Learning motivation is an impetus that exists in students to function as an effort in achieving their goals or 
achievements [13]. Learning motivation as a whole of the driving force that exists between students so that the desire to learn arises [14]. The nature of learning motivation is an internal and external encouragement to students who are learning to make changes in behavior, in general with several indicators or supporting elements [15].

Based on the above opinion, it can be concluded that the motivation have an important role in underlying various actions and behaviors of students who become backgrounds in certain conditions and situations and are carried out to achieve goals.

\subsection{Self-efficacy}

Self-efficacy is one aspect of self-knowledge which is the most influential in everyday human life because self-efficacy possesses influence the individual in determining the actions to be taken to achieve a goal, including estimates of the challenges.

Self-efficacy determines the amount of effort or tenacity done by someone facing a task or activity [16]. If someone has confidence that he/she will not be able to deal with certain tasks or activities, then he will quickly switch to other tasks or activities and do not want to make a greater effort to complete the task or activity. Self-efficacy is a personal factor that becomes an intermediary or mediator in the interaction between behavioral factors and environmental factors.

Self-efficacy as one of the most influential aspects of knowledge about oneself in everyday human life [17]. This is due to the self-efficacy that has influenced the individual in determining the actions to be taken to achieve the goals including the estimated events to be faced.

\subsection{Blended learning}

Blended learning is one solution to address the various needs of educational institutions throughout the world. Blended Learning is a combination of traditional classrooms and online learning. This learning provides the benefits of face-to-face learning and electronic learning. The main objective of this research is to assess the effect of blended learning in the teaching process in schools. Blended learning aims to find the right balance between face-to-face and online methods [18]. Blended learning transforms passive students who usually only receive knowledge, which is characteristic of traditional teaching models, into active students who build their knowledge [19][20]. At present, mixed learning abilities are well understood, and their flexibility, ease of access, and the integration of sophisticated multimedia and high technology have been taken into consideration [21]. This combination provides better learning outcomes [4].

Combining internet technology and face-to-face interaction can improve pedagogy and easier access to information [5]. Thus, blended teaching can facilitate an independent and collaborative learning experience. Blended learning builds a community of inquiry and a free and interactive dialogue platform. The students' way to speak supports mixed learning [6]. Digital literate students increase the possibility of expanding their learning and conversations outside the classroom [7]. The use of cellular technology in education offers new opportunities to integrate face-to-face learning and online learning [8]. The implementation of mobile learning and blended learning 
is not optimal due to the lack of design of the teaching system, for that mixed learning scenarios are used by combining various forms of learning and integrating various ways to access content using cellular technology. Teachers struggle to develop their teaching competencies in a context where reform and innovation are not the dominant problem. Research on technology-enhanced teacher education programs must discuss how 21st century skills frame training programs and how teachers or educators are prepared to become professional teachers [22].

Improved technology has changed the behavior and attitudes of students, and has changed the way they learn and communicate in and outside the classroom. The widespread use of digital technology has changed education. Therefore technology-based learning is needed. Integrating technology with face-to-face instruction can strengthen interactive and communicative learning environments and provide meaningful learning outcomes [4][23]. Fortunately, blended learning is versatile, so it depends on the instructor's decision when it comes to choosing from a variety of choices, depending on the learning context. Using blended learning can help improve students' academic self-efficacy and students' motivation.

\subsection{Students' achievement}

Achievement is the result of an activity that can be created, carried out and pleases, obtained by working hard, both individually and in groups. While the definition of learning achievement is a result of the act of making an assessment expressed by numbers or symbols, where all that is about the progress of student learning outcomes during a certain period [24]. That learning achievement is the culmination of learning outcomes that can reflect the results of student learning success towards the stated learning goals. Student learning outcomes can include aspects of cognitive (knowledge), affective (attitude), and psychomotor (behavior). Achievement of learning outcomes can be measured using learning achievement tests. 


\subsection{Framework}

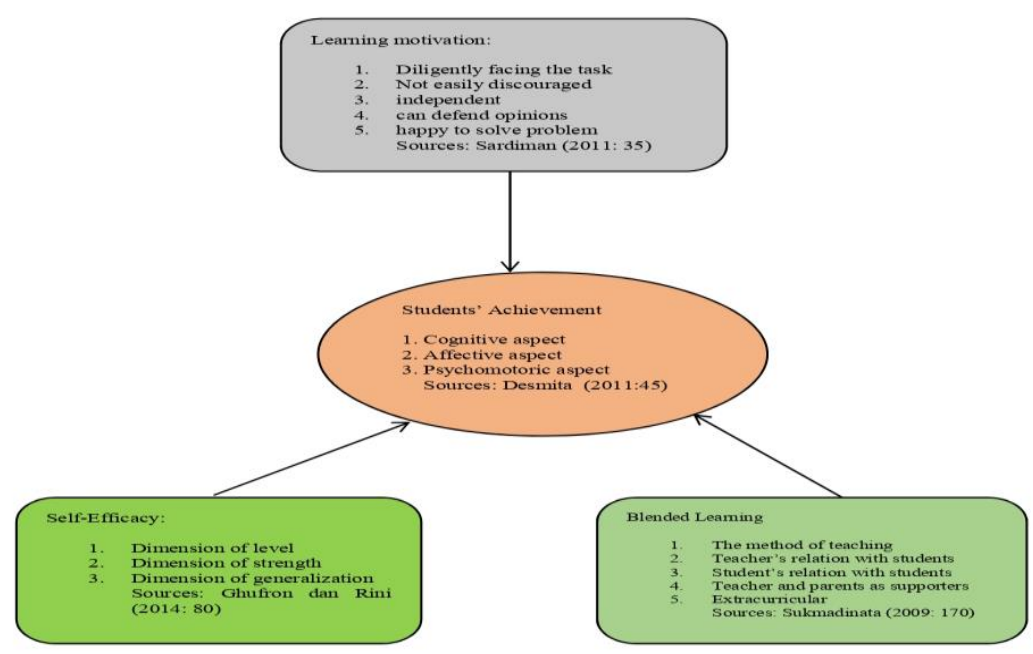

Fig. 1. Research Thinking Framework

\subsection{Hypothesis}

The initial hypothesis in this study are set as follows: (1) There is an influence of Learning Motivation on students' achievement of Public High School in Padang. (2) There is an effect of Self-Efficacy on students' achievement of Public High School in Padang. (3) There is an influence of Blended Learning on students' achievement of Public High School in Padang. (4) There is an effect of Motivation, Self-Efficacy, and Blended learning simultaneously on the students' achievement of Public High School in Padang.

\section{$3 \quad$ Method}

\subsection{Research design}

This type of research used for this research is to use descriptive-analytic research. Descriptive research methods have the objective to make a systematic, factual, and accurate description, description, or painting of the facts, properties, and relationships between the phenomena investigated [25]. Data obtained is using structured qualitative data, using a Likert scale 1-5, from strongly agree to disagree. In this study examines the effect of learning motivation, self-efficacy, and blended learning for the students' achievement of Public High School in Padang. 


\subsection{Variable operations}

The operational definition is to explain the concept of a variable that can be measured by its measurement parameters.

Table 3. Variable operational definitions

\begin{tabular}{|c|c|c|c|c|}
\hline Variable & Definition & Dimension & Indicators & Scale of Measure \\
\hline $\begin{array}{l}\text { Learning } \\
\text { motivation } \\
\quad(\mathrm{X} 1)\end{array}$ & \begin{tabular}{|l|} 
Internal and external \\
encouragement to \\
students who are \\
learning to make \\
changes in behavior, \\
generally some \\
indicators or ele- \\
ments that support
\end{tabular} & $\begin{array}{l}\text { Diligent; Do not } \\
\text { give up; Independ- } \\
\text { ent; Able to ex- } \\
\text { press opinions; } \\
\text { Happy to solve } \\
\text { problem }\end{array}$ & \begin{tabular}{|l|} 
1.Students show persever- \\
ance in working on assign- \\
ments to complete \\
2. Students never despair \\
when facing learning diffi- \\
culties \\
3. Students can study on \\
their own without having to \\
always be supervised by the \\
teacher \\
4. Students can defend their \\
opinions on a topic by \\
presenting arguments.
\end{tabular} & Likert \\
\hline $\begin{array}{l}\text { Self-Efficacy } \\
\text { (X2) }\end{array}$ & $\begin{array}{l}\text { Knowledge of self or } \\
\text { self-knowledge is the } \\
\text { most influential in } \\
\text { everyday human life }\end{array}$ & $\begin{array}{l}\text { 1. Level } \\
\text { 2. Strength } \\
\text { 3. Generalization }\end{array}$ & $\begin{array}{l}\text { 1.Students are confident in } \\
\text { their ability to solve difficult } \\
\text { problems } \\
\text { 2. Students are confident in } \\
\text { their competency } \\
\text { 3. Students can solve prob- } \\
\text { lems based on their under- } \\
\text { standing of the material }\end{array}$ & Likert \\
\hline $\begin{array}{c}\text { Blended } \\
\text { Learning (X3) }\end{array}$ & $\begin{array}{l}\text { Blended learning } \\
\text { combines the best } \\
\text { aspects of online } \\
\text { learning, structured } \\
\text { face-to-face activi- } \\
\text { ties, and real-world } \\
\text { practices. Online } \\
\text { learning system, } \\
\text { classroom exercises, } \\
\text { and on-the-job } \\
\text { experience }\end{array}$ & $\begin{array}{l}\text { 1. The method of } \\
\text { teaching } \\
\text { 2. Teacher rela- } \\
\text { tions with students } \\
\text { 3. Student relations } \\
\text { with students } \\
\text { 4. The state of the } \\
\text { classroom } \\
\text { 5.Extracurricular }\end{array}$ & $\begin{array}{l}\text { 1. The teacher's method of } \\
\text { teaching helps students } \\
\text { understand the lesson } \\
2 \text {. The teacher is can be a } \\
\text { place for student consulta- } \\
\text { tion on his lessons } \\
\text { 3. The communication } \\
\text { between classmates is very } \\
\text { good }\end{array}$ & Likert \\
\hline $\begin{array}{c}\text { Students' } \\
\text { Achievement } \\
\text { (X4) }\end{array}$ & $\begin{array}{l}\text { The peak of learning } \\
\text { outcomes that can } \\
\text { reflect the results of } \\
\text { student learning } \\
\text { success towards } \\
\text { learning goals has } \\
\text { been set }\end{array}$ & $\begin{array}{l}\text { 1. Cognitive } \\
\text { aspects } \\
\text { 2. Affective aspect } \\
\text { 3. Psychomotor } \\
\text { aspects }\end{array}$ & $\begin{array}{l}\text { 1. Your students follow all } \\
\text { lessons well } \\
\text { 2. Students can learn indi- } \\
\text { vidually or in groups } \\
\text { 3. Students show active } \\
\text { attitude in class }\end{array}$ & Likert \\
\hline
\end{tabular}

\subsection{Population and samples}

Population is a generalized area (read: leveling) consisting of objects / subjects that have certain qualities and characteristics determined by researchers to be studied and then drawn conclusions [25]. So the population is not only people, but also objects and other natural objects. The population is also not just the number of objects / sub- 
jects studied, but includes all the characteristics / properties possessed by the subject or object under study.

The sample is part of the number and characteristics possessed by the population. To determine the sample in the study various sampling techniques was used. The sampling technique is a sampling technique. The sample size cannot be less than 5\% of the population. To meet these criteria, sample measurements are calculated using the Slovin formula [25]. The population of Public High School in Padang was representing all levels of education is 120 students. Precision takes 5\% to maintain the representativeness of the study sample. Based on the formula above, there were 92 samples taken from Public High School in Padang. The sampling method used is simple random sampling.

\subsection{Data analysis}

After selecting the sample, making a model, determining the variables used in the study, and making hypothesis, the next step is processing data using Partial Least Square Version 3.0. Evaluation of the PLS model is done by evaluating the outer model and the inner model. The outer model is a measurement model to assess the validity and reliability of the model. Through the algorithm iteration process, the measurement model parameters (convergent validity, discriminant validity, composite reliability, and Cronbach's alpha) are obtained, including the value of R2 as a parameter of the accuracy of the predicted model. While the inner model is a structural model for predicting causality between latent variables. Through the bootstrapping process, t-statistic test parameters are obtained to predict the causality relationship.

\section{$4 \quad$ Result and Discussion}

Table 4. Significance Test Result

\begin{tabular}{|l|c|c|c|}
\hline \multicolumn{1}{|c|}{$\begin{array}{c}\text { Influence between } \\
\text { Variables }\end{array}$} & $\begin{array}{c}\text { Original sample } \\
(\mathbf{O})\end{array}$ & $\begin{array}{c}\text { T-Statistics } \\
(|\mathbf{O} / \mathbf{S T D E V}|)\end{array}$ & P Value \\
\hline Blended learning >> students' achievement & 0.351 & 3.841 & 0.000 \\
\hline Learning motivation -> Students' achievement & 0.256 & 2.112 & 0.006 \\
\hline Self-efficacy -> Students' achievement & 2.180 & 0.905 & 0.366 \\
\hline
\end{tabular}

Based on the above table, the following is an explanation of the results of the research hypothesis test:

Hypothesis 1: Learning Motivation influence on the Learning Achievement of Public High School in Padang. Based on Table 4, it appears that the value of the original sample estimate the Learning Motivation variable against the Students' Achievement variable is positive which is equal to 0.256 . Then, it was seen that the $t$ statistic was 2,112 P 1.96 and P Values $0.006<0.05$ [26]. So it can be said to have a significant effect. Thus, the H1 Hypothesis in this study was declared acceptable. In conclusion, Learning Motivation has a positive and significant effect on the Students' Achievement of Public High School in Padang. 
Hypothesis 2: Self-Efficacy influences Students' Achievement of Public High School in Padang. Based on Table 4, it can be seen that the value of the original sample estimate the Self-efficacy variable on the Students' Achievement variable is positive which equal is 0.218 . Then, the $\mathrm{t}$-statistic is $0.905 \leq 1.96$ and $\mathrm{P}$ Values is $0.366>$ 0.05 [26]. So it can be said to have no significant effect. Thus, the H2 Hypothesis in this study was declared rejected. In conclusion, Self-efficacy did not significantly influence on the students' achievement of Public High School in Padang.

Hypothesis 3: Blended Learning influences on the students' achievement of Public High School in Padang. Based on Table 4, it appears that the value of the original sample estimate Blended learning variable on the students' achievement variable is positive which is equal to 0.351 . Then, the t-statistic was $3,841 \geq 1.96$ and $\mathrm{P}$ Values $0,000<0.05$ [26]. So it can be said to have a significant effect. Thus, the H3 Hypothesis in this study was accepted. In conclusion, Blended learning has a positive and significant effect on the students' achievement of Public High School in Padang.

Hypothesis 4: Learning Motivation, Self-efficacy and Blended Learning together have an influence on Students' Achievement of Public High School in Padang. Based on Table 4, it can be seen that the original sample value estimates the Learning Motivation, Self-efficacy and positive variables which are equal to $0.019(0.256 * 0.218 *$ $0.351)$. Then, the t-statistic is $7.341(2.112 * 0.905 * 3.841) \geq 1.96$ [26]. So it can be said to have a significant effect. Thus, the H4 Hypothesis in this study was accepted. In conclusion, Learning Motivation, Self-effiacy, and Blended Learning simultaneously have a significant effect on the students' achievement of Public High School in Padang.

\section{Conclusion}

Although there are indicators that show an emerging need to integrate technology into face-to-face language classes, there are still some limitations that can be the subject of new research. The new generation is equipped with a digital background; thus the mixed learning approach can be very useful because it will improve the quality of learning and increase student access to information.

Integrating technology with face-to-face instruction can stimulate learning and provide a more collaborative learning experience. It is time for higher education to adjust to these changes to pursue increasing demands of both students and the workplace. Student involvement, motivation, and interaction are key factors in achieving a successful learning process. When students can connect what they learn with real-life and personalize it, they become more intrinsically motivated.

Based on the results of the study, here are some conclusions from this study

1. Learning Motivation has a positive and significant effect on students' achievement of Public High School in Padang

2. Self-Efficacy does not significantly influence students' achievement of Public High School in Padang

3. Blended learning has a positive and significant effect on students' achievement of Public High School in Padang 
4. Learning Motivation, Self-Efficacy, and Blended Learning together have a significant effect on students' achievement of Public High School in Padang.

\section{Acknowledgement}

This study was supported by BPPDN scholarship from the Ministry of Research, Technology, and Higher Education of the Republic of Indonesia.

\section{$7 \quad$ References}

[1] A. Benešová and J. Tupa, "Requirements for education and qualification of people in industry 4.0," in Procedia Manufacturing, 2017, vol. 11, pp. 2195-2202. http://creativecommons.org/licenses/by-nc-nd/4.0/

[2] Sunarti, "Pengaruh intelegensi dan motivasi belajar terhadap prestasi belajar siswa kelas X SMA Negeri 6 Purworejo," J. Oikoinomia, vol. 2, no. 4, 2013. http://ejournal.umpwr.ac.id/index.php/oikonomia/article/view/1929/1824

[3] N. Guan, J. Song, and D. Li, "on the advantages of computer multimedia-aidd english teaching," Procedia Comput. Sci., vol. 131, pp. 727-732, 2018. https://doi.org/10.10 16/j.procs.2018.04.317

[4] R. Garrison and N. Vaughan, Blended learning in higher education: framework, principles and guidelines. San Francisco: John Wiley \& Sons, Inc., 2008.

[5] C. J. Bonk and C. R. Graham, Handbook of blended learning: Global Perspectives, local designs. San Francisco: John Wiley \& Sons, Inc., 2009.

[6] M. Paechter and B. Maier, "Online or face-to-face? Students' experiences and preferences in e-learning," Internet High. Educ., vol. 13, no. 4, pp. 292-297, 2010. https://doi.org/10.1016/j.iheduc.2010.09.004

[7] N. Kasraie and A. Alahmad, "Investigating the reasons institutions of higher education in the USA and Canada utilize blended learning," Mevlana Int. J. Educ., vol. 41, no. 1, pp. 67-81, 2014.

[8] I. K. Suartama and P. Setyosari, "Development of an instructional design model for mobile blended learning in higher education,” Int. J. Emerg. Technol. Learn., vol. 14, no. 16, pp. 4-22, 2019. https://doi.org/10.3991/ijet.v14i16.10633

[9] N. S. Sukadinata, Metode penelitian pendidikan. Bandung: Remaja Rosdakarya, 2007.

[10] C. Chotimah, "Pengembangan modul biologi dengan strategi pembelajaran think pair share sebagai upaya meningkatkan motivasi belajar, sikap sosial, kemampuan berfikir kritis dan hasil belajar kognitif siswa SMK Kota Malang," 2017. [Online]. Available: http://karyailmiah.um.ac.id/index.php./disertasi/article/view/61099. [Accessed: 14-Oct-2019].

[11] E. R. Umboh, B. J. Kepel, and R. S. Hamel, "Hubungan antara motivasi belajar dengan prestasi akademik pada mahasiswa program studi ilmu keperawatan fakultas kedokteran Universitas Sam Ratulangi Manado,” e-journal Keperawatan (e-Kp), vol. 5, no. 1, 2017. https://media.neliti.com/media/publications/108275

[12] A. B. Susilo, "Pengembangan model pembelajaran ipa berbasis masalah untuk meningkatkan motivasi belajar dan berpikir kritis," J. Pendidik. dan Pengajaran, vol. 22, no. 2, pp. 213-131, 2012. http://journal.unnes.ac.id/artikel sju/jpe/58

[13] N. Hidayati, "Peningkatkan motivasi belajar mahasiwa terhadap prestasi belajar aljabar matriks," Aksioma J. Pendidik. Mat. FKIP Univ. Muhammadiyah Metro, vol. 6, no. 1, pp. 28-32, 2017. 
[14] Sardiman, Interaksi dan motivasi belajar mengajar. Jakarta: Raja Grafindo Persada, 2011.

[15] H. B. Uno, Teori motivasi dan pengukurannya: analisis dibidang pendidikan. Jakarta: Bumi Aksara, 2011.

[16] Bandura, "Guide for constructing self-efficacy scales," in Self efficacy beliefs of adolescents, Fajares and T. Urdan, Eds. Greenwich: Information Age Publishing, 2002.

[17] M. N. Ghufron and R. R. S., Teori-teori psikologi. Yogyakarta: ArRuzz Media, 2010.

[18] C. E. Morton et al., "Blended learning: how can we optimise undergraduate student engagement ?," BMC Med. Educ., vol. 16, pp. 1-8, 2016. https://doi.org/10.1186/s12909$\underline{016-0716-\mathrm{Z}}$

[19] E. M. T. Maza, M. T. G. Lozano, A. C. C. Alarcón, L. M. Zuluaga, and M. G. Fadu, "Blended learning supported by digital technology and competency-based medical education: a case study of the social medicine course at the Universidad de los Andes, Colombia," Int. J. Educ. Technol. High. Educ., vol. 13, pp. 1-13, 2016. https://doi.org/10.1186/s41239-016-0027-9

[20] S. Wichadee, "A development of the blended learning model using edmodo for maximizing students' oral proficiency and motivation," iJET, vol. 12, no. 2, pp. 137-154, 2017. https://doi.org/10.3991/ijet.v12i02.6324

[21] L. Johnson, S. Adams Becker, M. Cummins, V. Estrada, A. Freeman, and C. Hall, The NMC horizon report: 2016 higher education edition. Austin, Texas: The New Media Consortium, 2016.

[22] J. F. Matos, A. Pedro, and J. Piedade, "Integrating Digital Technology in the School Curriculum University of Lisbon, lisbon, Portugal," iJET, vol. 14, no. 21, pp. 4-15, 2019. https://doi.org/10.3991/ijet.v14i21.10863

[23] J. E. Rooney, "Blended learning opportunities to enhance educational programming and meetings," Assoc. Manage., vol. 55, pp. 26-32, 2003. https://doi.org/10.1016 /j.sbspro.2015.04.086

[24] S. Suryabrata, Metodologi penelitian. Jakarta: Raja Grafindo Persada, 2008.

[25] Sugiyono, Metode penelitian pendidikan (pendekatan kuantitatif, kualitatif, dan R\&D). Bandung: Alfabeta, 2013.

[26] I. Ghozali, Model persamaan struktural: konsep dan aplikasi dengan program AMOS 24 update bayesian SEM Edisi 7. Semarang: Universitas Diponegoro, 2014.

\section{Authors}

Ryan Hidayat Rafiola is a doctorate students of Universitas Negeri Malang, Malang, Indonesia. He is currently teachingat at the STKIP PGRI Sumatera Barat, Padang, Indonesia. His research interests include Counseling, e-learning, Cognitive Behavior Approach, Educational Psychology, live modeling, Theoretical Model, Cultural Approach in Counseling etc.

Punaji Setyosari is a professor in the post Graduate program of the Department of Education and Technology, Universitas Negeri Malang, Malang, Indonesia. His research interests include research methodologies, evaluation and assessment, instructional media, problem-based learning, and collaborative learning. His scopus ID: 57191276640

Carolina Ligya Radjah is a lecturer in the post Graduate program of the Department of Guidance and Counseling, Universitas Negeri Malang, Malang, Indonesia. Her research interests include Counselng, Self-efficacy Academic, Achievement Mo- 
tivation, Elaboration Model, Theoretical Model, Cognitive Behavior Approach, Group Counseling, Cultural Approach in Counseling, Educational Psychology, and etc.

M. Ramli is a lecturer in the post Graduate program of the Department of Guidance and Counseling, Universitas Negeri Malang, Malang, Indonesia. His research interests include Counselng, Cognitive Behavior Approach, Group Counseling, Cultural Approach in Counseling, Evaluation And Supervision Counseling and Guidence, Non-Test Technical Assessment, Educational Psychology, and etc.

Article submitted 2019-11-28. Resubmitted 2020-01-10. Final acceptance 2020-01-13. Final version published as submitted by the authors. 